\title{
Design and content validation of a survey questionnaire assessing the determinants of human papillomavirus (HPV) vaccine hesitancy in France: A reactive Delphi study
}

\author{
Fadia Dib $^{\mathrm{a}, \mathrm{b}, *}$, Philippe Mayaud ${ }^{\mathrm{c}}$, Odile Launay ${ }^{\mathrm{d}, 1}$, Pierre Chauvin ${ }^{\mathrm{a}, 1}$, the FSQD-HPVH Study Group ${ }^{2}$ \\ a INSERM, Sorbonne Université, Institut Pierre Louis d'Épidémiologie et de Santé Publique, Paris, France \\ ${ }^{\mathrm{b}}$ INSERM CIC 1417, F-CRIN, I REIVAC, Assistance Publique- Hôpitaux de Paris, Hôpital Cochin, Paris, France \\ ${ }^{\mathrm{C}}$ London School of Hygiene and Tropical Medicine, London, United Kingdom \\ ${ }^{\mathrm{d}}$ Université de Paris, Faculté de médecine Paris Descartes, INSERM CIC 1417, F-CRIN, I REIVAC; Assistance Publique- Hôpitaux de Paris, Hôpital Cochin, Paris, France
}

\section{A R T I C L E I N F O}

Article history:

Received 16 December 2019

Received in revised form 9 July 2020

Accepted 13 July 2020

Available online $\mathrm{xxxx}$

\section{Keywords:}

Human papillomavirus (HPV)

Vaccine

Vaccine hesitancy

Determinants

Questionnaire

Delphi study

\begin{abstract}
A B S T R A C T
Introduction: This study aimed to develop and undertake a preliminary validation of a French Survey Questionnaire for the Determinants of HPV Vaccine Hesitancy (FSQD-HPVH).

Methods: We undertook an electronic-based Delphi consultation among a panel of Francophone experts in two rounds. Round 1 consisted of the assessment of a structured questionnaire comprising of three parts ((i) Contextual influences, (ii) Individual and group influences, and (iii) Vaccine/vaccinationspecific issues), in line with the WHO Strategic Advisory Group of Experts (SAGE) Vaccine Hesitancy (VH) Model of Determinants. Items included in this questionnaire were based on a literature review. Definitions of the factors included in the SAGE model were provided in the questionnaire. The panel of experts was asked to score each item using a 3-point Likert scale, in which 1 meant "Essential", 2 "Useful but not essential", and 3 "Not necessary". The panel was also invited to comment on the clarity/ comprehension of the questions and suggest reformulations/additional items. Lawshe's Content Validity Ratio (CVR) was computed to assess the level of consensus for each statement. Only items upon which agreement was not reached in Round $1(\mathrm{CVR}<0.6)$ and newly proposed items were submitted for evaluation in Round 2, using the same procedure.

Results: Fifteen experts completed the two rounds. Of 83 items evaluated in Round 1, 35 (42\%) had a CVR $\geq 0.6$ and were accepted without modification. In Round 2, 66 items were submitted to the same panel and consensus was reached for $22(33 \%)$ items using the threshold of 0.6. The final FSQD-HPVH version includes 57 items.

Conclusion: This study developed a survey instrument for the evaluation of HPV VH in France with good content validity. It will be used to assess the determinants of HPV VH, the first step towards an evidencebased approach to improving HPV vaccination rates in France.
\end{abstract}

(c) 2020 Elsevier Ltd. All rights reserved.

\section{Introduction}

In a global study conducted by the Wellcome Trust in over 140 countries, France was identified as the country with the lowest

\footnotetext{
* Corresponding author at: Institut Pierre Louis d'Epidémiologie et Santé Publique, UMRS 1136 - 27 rue de Chaligny, 75012 Paris, France.

E-mail address: Fadia.dib@inserm.fr (F. Dib).

1 The French Survey Questionnaire for the Determinants of HPV vaccine Hesitancy (FSQD-HPVH) Study Group: Themistoklis Apostolidis, Celine Audiger, Anne-Sophie Barret, François Beck, Aymery Constant, Mady Denantes, Eve Dube, Emilie Karafillakis, Liliane Keros, Joseph Monsonego, Isabelle Parizot, Melinda Petroiac, Sylvie Quelet, Pia de Reilhac, Nicolas Vignier.

2 The two last authors contributed equally to the work.
}

confidence in vaccine safety with "one in three people disagree that vaccines are safe" [1]. In this context, vaccination to prevent human papillomavirus (HPV) infection, the most common sexually transmitted infection (STI) worldwide and the etiological agent of a range of conditions including anogenital and oropharyngeal cancers, is one of the most challenging in France.

In 2019, HPV vaccination in France is recommended for all girls aged $11-14$ years and for those aged $15-19$ years as a catch-up strategy. It is also recommended for girls and boys with immune deficiency conditions at ages 11-19, and for men who have sex with men (MSM) up to the age of 26 [2]. The Ministry of Health is considering widening the target groups to include boys as the same ages of girls. Recently, the French National Authority for 
Health (HAS) (an independent public scientific advisory body) issued a favourable opinion on the widespread vaccination of boys [3].

HPV vaccination in France relies on individual initiative, requires parental authorization for those under 18 years, and is prescribed and administered by medical doctors. It can also be administered by nurses with a medical prescription. It is costly and only partially (65\%) reimbursed by the National Health Insurance Fund, but those covered by a voluntary private health insurance (more than $95 \%$ of the French population [4]) or by the Subsidized Supplementary Health Insurance ("Complémentaire santé solidaire"/ CSS, granted for individuals whose income is below a given ceiling) are fully reimbursed.

Twelve years after its introduction, HPV vaccine uptake in France remains low, despite the extensive safety data accumulated for this vaccine both nationally and internationally [5-8]. In 2018, the estimated coverage rate for full (two-dose) HPV vaccination was estimated at $23.7 \%$ in girls aged 16 years [9], well below the objective of a $60 \%$ coverage for a two-dose vaccination set by the National Cancer Control Plan (NCCP) 2014-2019 [10], and the coverage reached in other European countries, which ranged from less than $40 \%$ in Germany [11] to more than $85 \%$ in the United Kingdom [12].

Addressing the challenge of improving HPV vaccine coverage has been on the French government's and public health agencies' agenda since 2009. The second NCCP (2009-2013) aimed to improve the uptake of HPV vaccination in 14-year-old girls through the dissemination of appropriate information to the public on the HPV vaccination while emphasizing that cervical cancer screening using a cervical smear is still essential from the age of 25 onwards [13]. The current (third) NCCP 2014-2019 has aimed to improve the uptake by increasing access to the vaccines in free vaccination canters and by training healthcare professionals [10].

The reasons for the low HPV vaccination coverage in France remain unclear [14-17]. There are conflicting data on the role of socioeconomic status in vaccine uptake. In a large study using the French National Health Insurance Database, the authors concluded that no clear factor was identified as a vaccination determinant; they suggested that complex associations between socioeconomic and cultural factors could explain the low HPV vaccination coverage [15]. A European survey estimated that only 56\% of French parents intended to have their eligible daughters vaccinated (versus 67\% in the United Kingdom) [18]. Furthermore, Verger and colleagues have found in a national panel of 1712 general practitioners (GPs) that $28 \%$ did not recommend HPV vaccines to young girls [19], raising the issue of the negative influence of GPs in vaccination decision-making.

The phenomenon known as "vaccine hesitancy" may partly explain low HPV vaccine coverage in France. This term refers to a complex, multifaceted phenomenon which occurs within a spectrum, from full and partial, to no vaccination. It is defined by the World Health Organization (WHO) Strategic Advisory Group of Experts (SAGE) vaccine hesitancy working group as "the delay in acceptance or refusal of vaccines despite availability of vaccination services (...) It is influenced by factors such as complacency, convenience and confidence"[20]. The prevalence of vaccine hesitancy
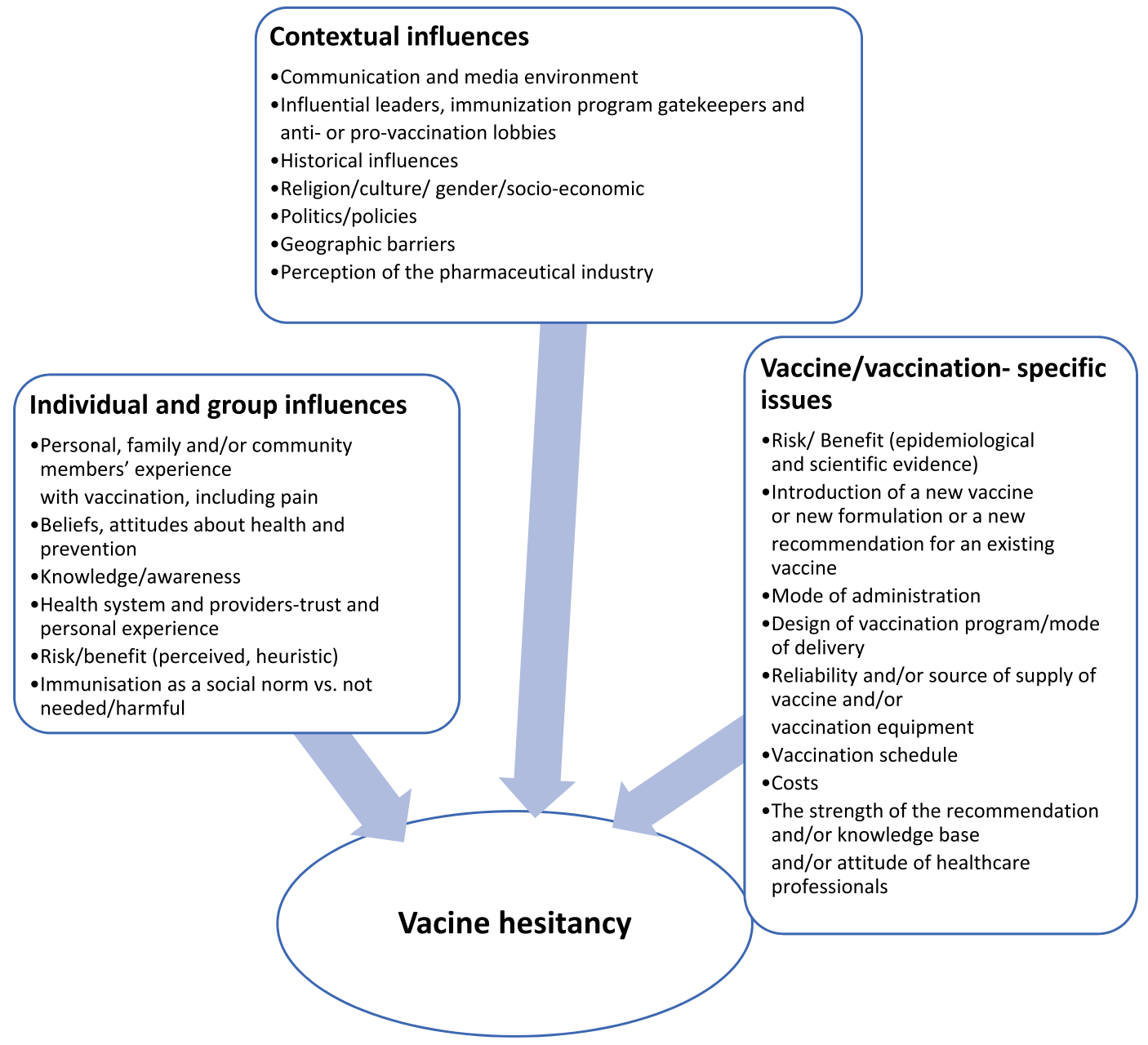

Fig. 1. Conceptual framework of vaccine hesitancy and its determinants (Strategic Advisory Group of Experts model). 
is estimated to be $48 \%$ (95\% confidence interval [CI] 45.1-51.4) among French parents of adolescent girls aged $11-15$ years; it is particularly high among those with a higher education level [21].

Hesitancy and its adverse impacts on vaccine uptake rates have been increasingly recognized by the WHO Strategic Advisory Group of Experts (SAGE) on Immunization, leading to the publication in 2015 of a compendium of tools to measure vaccine hesitancy [22]. These tools include a matrix of vaccine hesitancy determinants organized in three main categories of survey questions: (i) contextual influences (e.g., cultural reasons, communication and social media), (ii) individual and group influences (e.g., immunization as a social norm versus not needed/harmful, distrust in the vaccine and lack of perceived benefit of the vaccine), and (iii) vaccine/vaccination-specific issues (e.g., vaccination schedule, costs, and strength of the recommendation and/or attitude of healthcare professionals). This tool is a useful comprehensive approach to help diagnose major determinants of vaccine hesitancy (Fig. 1). However, it was not designed as a survey-ready format for straightforward use in investigational activities, as acknowledged by the Working Group [22]. Besides, the questions displayed in this matrix address vaccines in general, not the HPV vaccine in particular. This matrix was developed following a systematic review of existing research, the findings from an immunization managers' survey of vaccine hesitancy and expert consultation [23].

The problem at the heart of the failed efforts to increase HPV vaccination coverage may lie in the inability in identifying and addressing the actual root causes of vaccine hesitancy and refusal. It is, therefore, crucial to gain a greater understanding of the determinants of HPV vaccine hesitancy in the French context so that targeted interventions can be developed accordingly. There is currently no specific tool to assess the determinants of HPV vaccine hesitancy in France. This study aimed to develop and validate a specific French Survey Questionnaire for the Determinants of HPV Vaccine Hesitancy (FSQD-HPVH) to be later administered to mothers of girls of eligible to HPV vaccination, using the SAGE Working Group Determinants of Vaccine Hesitancy Matrix. Preliminary validation was undertaken through assessment of the items for content validity, i.e., the extent to which they are reflective of the factors considered in the SAGE working group model [24].

\section{Materials and Methods}

\subsection{Study design}

A two-round modified electronic Delphi methodology was implemented using an instrument developed in the online Research Electronic Data Capture (REDCap) survey system hosted at the Pierre Louis Institute of Epidemiology and Public Health (IPLESP), Paris Sorbonne University. REDCap is a secure, webbased software platform designed to support data capture for research studies [25]. We used a Delphi approach since it is a universally recognized scientific technique for tapping individual judgments among experts from varying practices to build consensus [26,27]. The Delphi methodology, developed by the Rand Corporation, is a structured approach to group interaction using self-completed questionnaires. Through an iterative process of consultation rounds, the members of the group (the "experts") can reconsider their responses to the questionnaire after receiving feedback about how their responses compare to those from the rest of the group. The numbers of iterations of experts review and consensus criteria were established before starting the study $[28,29]$. Each panel member responded to the questionnaire individually and independently, unbiased by the identity and opinions of other panellists.

\subsection{Delphi panel selection}

The study scientific committee (comprised of FD, PC, and OL) identified potential participants providing a range of expertise and professional representation to ensure a broad knowledge base on the issue of HPV vaccine hesitancy. Experts were selected if they satisfied the following criteria: (1) had been engaged in clinical or research work related to the field of vaccination or HPV for at least 3 years and, (2) were based in France or spoke French. There are no hard rules for the number of Delphi panel participants, however, a panel of 10 to 18 experts is generally recommended [30]. Thus, we decided to invite at least twice the recommended number of panellists, allowing for a minimum 50\% participation rate. In May 2019, we e-mailed invitation letters, including the information on the aim of the study and a description of the Delphi study procedures to each potential panel member. Willing participants completed a brief form regarding their demographic and professional data.

\subsection{Survey instrument}

Following an extensive literature review, the scientific committee drafted a list of items, covering the three main thematic categories ((i) contextual, (ii) individual and group and (iii) vaccine/vaccination specific influences) and sub-categories of the Working Group Determinants of Vaccine Hesitancy Matrix.

All of the matrix sub-categories were covered in our instrument, except "Geographic barrier" (which may be best assessed by objective measures such as indicators of health care supply in the area of residence), "Mode of administration" (which is unlikely to be a sizable concern in teenagers as opposed to babies and very young children), "Risk/benefit of scientific and epidemiologic evidence" and "Influential leaders, gatekeepers and anti-vaccination lobbies" (whose related items could fit another matrix category; for example, an item about past issues regarding another vaccine could also fit the "Historical influences" category - a limit of the matrix which has been described previously [31]). The survey instrument was developed in French. In addition, 19 items were taken from the HPV Attitudes and Beliefs Scale [32] (HABS) and 19 from the HPV General Knowledge and HPV Vaccination Knowledge Scales [33], all of which have been validated in the FrenchCanadian setting. When drawing from this instrument, we paid particular attention to the need for transcultural adaptation, and so we slightly reworded/reformulated 12 of the French-Canadian items. One item on religion was taken from the Vaccine Confidence Project $^{\mathrm{TM}}$ [34]. Five items were taken from the Holistic Complementary and Alternative Medicine Questionnaire (HCAMQ) [35]. As there is no version of the HCAMQ validated in French, translation was performed. An initial translation (English into French) was performed by two French native-speaking authors (FD and PC). Back-translation (French to English) was then independently performed by a third author (PM, non-English native speaker but a fluent-speaking researcher who has been working in the UK for almost three decades). The list of websites information was drawn from the Vaccine Confidence Project ${ }^{\mathrm{TM}}$ data [36]. Items that did not reach consensus and have not either attracted specific suggestion for reformulation were recirculated without modification in the wording.

\subsection{Round 1}

In June 2019, we launched the first round of our modified reactive Delphi consultation by sending the structured questionnaire to the expert panellists. Different from the traditional first stage of Delphi procedure which requests participants to deliver new thoughts on their own, we asked the experts panel to react to 
the items that we had pre-generated, hence the "reactive" feature of our Delphi study [37]. The items included the set of response options if the questions required modalities of responses other than a numeric rating scale, i.e., yes/no or true/false/I do not know. Experts were queried as to whether or not each of the items proposed by the scientific committee was essential to assess a specific factor on a 3-point Likert scale, in which 1 point meant "Essential"; 2 "Useful but not essential", and 3 "Not necessary". Besides, experts were also invited to comment on items clarity/comprehension and suggest items potentially missing. As per the experts' comments, the scientific committee reworded original items that did not reach consensus and generated new ones.

\subsection{Round 2}

Two months later, in August 2019, we e-emailed individualized questionnaires to those experts who had returned Round 1 responses. Only items upon which consensus was not reached in Round 1 were retained for re-assessment in Round 2 [38], thereby allowing experts to focus on the questionable items and consider changing their score (especially for those that have been reformulated) [39] while reducing participant dropouts due to a burdensome questionnaire. For each statement, participants were shown their initial individual evaluation (which could be confirmed or modified) and feedback from the Round 1: frequency distribution of the ratings (thereby showing the general extent of agreement in the experts' opinions) and a summary of anonymous comments made by the panel on Round 1. Participants were asked to re-rate the items using the same method as in Round 1 . The possibility to amend previous scores, taking into consideration the overall picture is a fundamental part to reach consensus. Participants were also asked the rate the newly generated items, in line with the suggestions of Round 1. Participants were asked to return Round 2 responses within four weeks, with the help of e-mail reminders. The survey instrument was finalised by excluding the questions that did not reach consensus in Round 2.

\subsection{Data analysis}

Lawshe's Content-Validity Ratio (CVR) was computed after each round to assess the consensus level for each statement. The CVR measures agreement among raters regarding how a particular item is essential to a particular construct. It is a function of the number of participants and their ratings and ranges from -1 to 1 . When fewer than half of the participants rate the item as "essential," the CVR is negative, when half rate the item as "essential" and half do not, the CVR is 0 and when all rate "essential," the CVR is 1 . The formula for computing the CVR is CVR $=(n-N / 2) /(N / 2)$, where $\mathrm{n}=$ the number of participants rating the item as "essential" and $\mathrm{N}=$ the total number of participants. Items with CVR values equal to or greater to a certain threshold (determined according to the number of respondents) were considered excellent in agreement evaluation [40]. Traditionally, Lawshe's method requires experts to provide their ratings just once, and items are immediately discarded if they fail to meet the minimum critical value. In this study, we decided to subject the items that did not reach the minimum critical value to further evaluation (whether as initially formulated or reformulated as per the experts' comments). This conservative approach ensured no question would be missed out, given the complexity and multifaceted nature of HPV vaccine hesitancy.

Demographic data of the experts' panel, the percentages of responses to each statement, and the CVR were analysed using SAS (version 9.4, SAS Institute Inc., Cary North Carolina).

\subsection{Ethics statement}

In France, ethics approval is not required for research that does not involve patients. The written invitations to the experts requesting them to participate in the study incorporated items conveying confidentiality procedures, and the prerogative to erase their data and thus revoke participation at any time. Data privacy and confidentiality of all participants were ensured, although total anonymity could not be achieved due to the need to directly e-mail participants. However, participant identities were known only to the main author, and participants were unaware of the identities of the other panel members.

\section{Results}

\subsection{Panel composition and response rates}

Of the 40 potential panel members invited to participate in the study, 18 (45\%) responded and sent their demographic data. Of them, 15 (6 health care professionals and 9 non-clinicians academics/researchers) sent back Rounds 1 and 2 questionnaires. Panel members were all based in France, except two, based in Canada and the UK (Table 1). For 15 participants, the minimum critical value of the content validity ratio (CVR) was calculated to be 0.6 (Round 1 ) at $\alpha=5 \%$.

\subsection{Round 1}

In Round 1, 83 items were evaluated by the expert panel, and participants gave comments on 66 items (79\%). A total of 35 (42\%) items reached or exceeded the CVR minimum critical value and were set aside for inclusion in the final questionnaire. The analysis of the CVR of the individual items is shown in Table 2. Items rated "essential" by all the experts pertained to "Knowledge/awar eness", "Communication and media environment", "Immunisation as a social norm versus not needed/harmful" and "The strength of the recommendation and/or knowledge base and/or attitude of healthcare professionals" factors.

Table 1

Demographic and professional characteristics of the expert panel $(n=15)$.

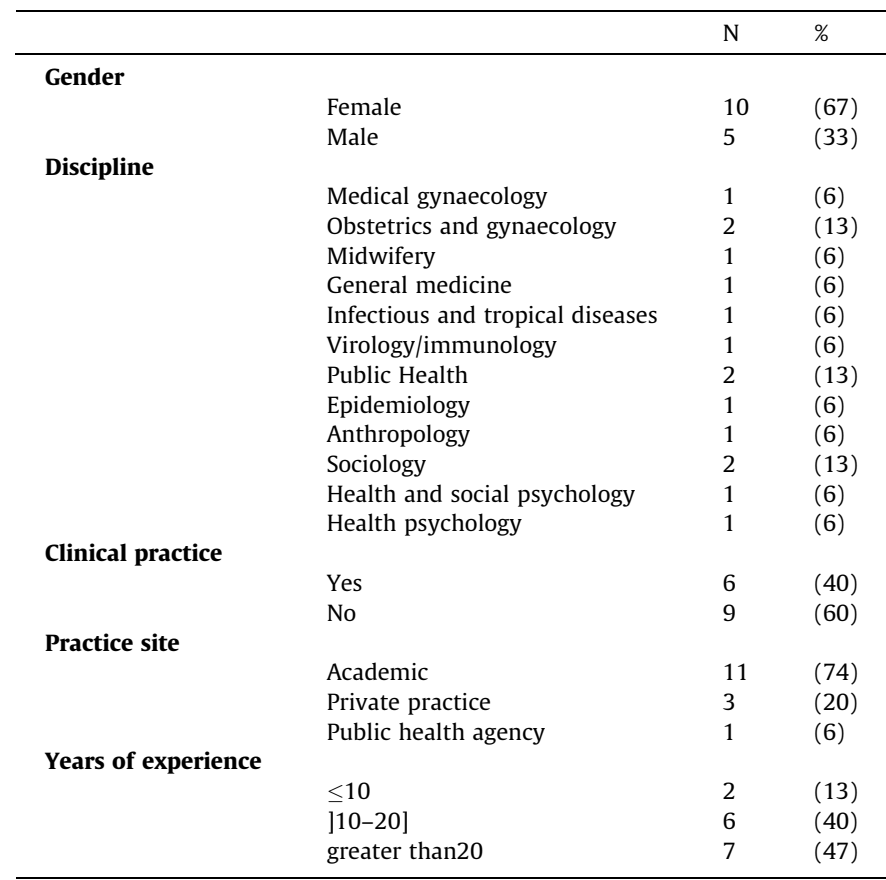


Table 2

Measures of agreement and content validity ratio from Rounds 1 and 2.

\begin{tabular}{|c|c|c|c|c|c|c|c|c|c|}
\hline \multirow[b]{2}{*}{ Factor } & \multirow[b]{2}{*}{ Initial item } & \multicolumn{3}{|c|}{ Round $1(\mathrm{n}=15)$} & \multirow[b]{2}{*}{ Reformulated item } & \multirow[b]{2}{*}{ Additional item } & \multicolumn{3}{|c|}{ Round $2(n=15)$} \\
\hline & & $\mathrm{N}$ & $\begin{array}{l}\text { \% agreement } \\
\text { for "essential" }\end{array}$ & $\begin{array}{l}\text { Content } \\
\text { Validity } \\
\text { Ratio }\end{array}$ & & & $\mathrm{n}$ & $\begin{array}{l}\% \\
\text { agreement } \\
\text { for } \\
\text { "essential" }\end{array}$ & $\begin{array}{l}\text { Content } \\
\text { Validity } \\
\text { Ratio }\end{array}$ \\
\hline \multirow{5}{*}{$\begin{array}{l}\text { Contextual factors } \\
\text { Communication and media } \\
\text { environment }\end{array}$} & & & & & & & & & \\
\hline & $\begin{array}{l}\text { I think that there is sufficient } \\
\text { communication on vaccination, in } \\
\text { general }\end{array}$ & 15 & 60 & 0.20 & $\begin{array}{l}\text { I think there is enough official } \\
\text { information campaigns about } \\
\text { vaccination in general }\end{array}$ & - & 15 & 67 & 0.33 \\
\hline & $\begin{array}{l}\text { I think that there is sufficient } \\
\text { communication on HPV vaccination } \\
\text { in particular }\end{array}$ & 15 & 73 & 0.47 & $\begin{array}{l}\text { I think there is enough official } \\
\text { information campaigns about HPV } \\
\text { vaccination in particular }\end{array}$ & - & $14^{\mathrm{a}}$ & 71 & 0.43 \\
\hline & $\begin{array}{l}\text { How did you hear about the HPV } \\
\text { vaccine? Recommendation of the } \\
\text { attending physician/ } \\
\text { Recommendation of a paediatrician/ } \\
\text { Recommendation of a gynaecologist/ } \\
\text { Television/Social media/ Written } \\
\text { press/Family /Friends/School / Other }\end{array}$ & $14^{\mathrm{a}}$ & 100 & $\mathbf{1}^{*}$ & - & - & - & - & - \\
\hline & $\begin{array}{l}\text { A lot of information and testimonials } \\
\text { have been reported, which one (s) } \\
\text { have worried you the most? The HPV } \\
\text { vaccine can give multiple sclerosis / } \\
\text { The HPV vaccine is responsible for the } \\
\text { increase in the number of cancers of } \\
\text { cervical cancer/ The HPV contains } \\
\text { mercury, which is harmful to health/ } \\
\text { The HPV vaccine contains aluminium, } \\
\text { which is harmful to health/Other/ } \\
\text { None }\end{array}$ & 15 & 71 & 0.43 & $\begin{array}{l}\text { Identical item with the addition of the } \\
\text { response mode "I have not heard } \\
\text { about it " for each proposal }\end{array}$ & - & $14^{\mathrm{a}}$ & 71 & 0.43 \\
\hline \multirow[t]{3}{*}{ Historical influences } & $\begin{array}{l}\text { Since the H1N1 influenza scandal, I } \\
\text { have less confidence in the healthcare } \\
\text { system }\end{array}$ & 15 & 73 & 0.47 & $\begin{array}{l}\text { Since the controversy over } \\
\text { vaccination against H1N1 flu, I have } \\
\text { less confidence in French vaccination } \\
\text { recommendations }\end{array}$ & - & 15 & 87 & $0.73^{*}$ \\
\hline & $\begin{array}{l}\text { Since the controversy over the } \\
\text { hepatitis B vaccine, I have less } \\
\text { confidence in the healthcare system }\end{array}$ & 15 & 80 & $0.60^{*}$ & - & - & - & - & - \\
\hline & $\begin{array}{l}\text { The scandal of the Mediator** makes } \\
\text { me doubt the integrity of the } \\
\text { healthcare system }\end{array}$ & 15 & 67 & 0.33 & $\begin{array}{l}\text { The Mediator's case makes me doubt } \\
\text { the integrity of the health system }\end{array}$ & - & 15 & 67 & 0.33 \\
\hline \multirow[t]{4}{*}{$\begin{array}{l}\text { Religion/culture/gender/socio- } \\
\text { economic }\end{array}$} & $\begin{array}{l}\text { With regard to religion, do you have a } \\
\text { regular religious practice/an } \\
\text { occasional religious practice/no } \\
\text { practice, but the feeling of belonging } \\
\text { to a religion/neither practice nor } \\
\text { feeling of belonging? }\end{array}$ & 15 & 60 & 0.20 & - & - & 15 & 53 & 0.07 \\
\hline & $\begin{array}{l}\text { (If practice religious/sense of } \\
\text { belonging) Is the HPV vaccine } \\
\text { compatible with your religious } \\
\text { beliefs? }\end{array}$ & 15 & 67 & 0.33 & - & - & 15 & 67 & 0.33 \\
\hline & $\begin{array}{l}\text { I think that vaccinating girls against } \\
\text { HPV encourages them to have sex }\end{array}$ & 15 & 93 & $0.87^{*}$ & - & - & - & - & - \\
\hline & $\begin{array}{l}\text { The fact that the HPV vaccine protects } \\
\text { against a sexually transmitted } \\
\text { infection makes me hesitate to } \\
\text { vaccinate my daughter }\end{array}$ & 15 & 53 & 0.07 & $\begin{array}{l}\text { I hesitate to get my daughter } \\
\text { vaccinated against the } \\
\text { papillomavirus because it is a } \\
\text { sexually transmitted infection }\end{array}$ & - & 15 & 67 & 0.33 \\
\hline
\end{tabular}




\begin{tabular}{|c|c|c|c|c|c|c|c|c|c|}
\hline \multirow[b]{2}{*}{ Factor } & \multirow[b]{2}{*}{ Initial item } & \multicolumn{3}{|c|}{ Round $1(\mathrm{n}=15)$} & \multirow[b]{2}{*}{ Reformulated item } & \multirow[b]{2}{*}{ Additional item } & \multicolumn{3}{|c|}{ Round $2(\mathrm{n}=15)$} \\
\hline & & $\mathrm{N}$ & $\begin{array}{l}\% \text { agreement } \\
\text { for "essential" }\end{array}$ & $\begin{array}{l}\text { Content } \\
\text { Validity } \\
\text { Ratio }\end{array}$ & & & $\mathrm{n}$ & $\begin{array}{l}\% \\
\text { agreement } \\
\text { for } \\
\text { "essential" }\end{array}$ & $\begin{array}{l}\text { Content } \\
\text { Validity } \\
\text { Ratio }\end{array}$ \\
\hline & $\begin{array}{l}\text { It is hard to talk to my daughter about } \\
\text { her sexual health } \dagger\end{array}$ & 15 & 60 & 0.20 & - & - & 15 & 87 & $0.73^{*}$ \\
\hline & $\begin{array}{l}\text { I am not comfortable discussing my } \\
\text { daughter's sexual health with a } \\
\text { doctor/health care provider } \dagger\end{array}$ & 15 & 73 & 0.47 & $\begin{array}{l}\text { I feel uncomfortable discussing my } \\
\text { daughter's sexual health with a } \\
\text { doctor or another health } \\
\text { professional }\end{array}$ & - & 15 & 93 & $0.87^{*}$ \\
\hline & $\begin{array}{l}\text { Sex is not a subject I talk about with } \\
\text { my daughter } \dagger\end{array}$ & 15 & 53 & 0.07 & $\begin{array}{l}\text { Sexuality is a subject I approach with } \\
\text { difficulty with my daughter }\end{array}$ & - & 15 & 73 & 0.57 \\
\hline & $\begin{array}{l}\text { I am not comfortable talking to my } \\
\text { daughter about the HPV vaccine } \dagger\end{array}$ & 15 & 53 & 0.07 & $\begin{array}{l}\text { I am uncomfortable talking to my } \\
\text { daughter about the HPV vaccine }\end{array}$ & - & 15 & 73 & 0.57 \\
\hline & $\begin{array}{l}\text { I do not know how to approach the } \\
\text { topic of HPV vaccine with my } \\
\text { daughter } \dagger\end{array}$ & 15 & 73 & 0.47 & $\begin{array}{l}\text { I have difficulty in addressing the } \\
\text { subject of HPV vaccine with my } \\
\text { daughter }\end{array}$ & - & 15 & 93 & $0.87^{*}$ \\
\hline \multirow[t]{3}{*}{ Politics/policies } & $\begin{array}{l}\text { I am favourable to the } 11 \text { vaccines } \\
\text { mandatory for children born since } \\
\text { January } 1 \text { st, } 2018\end{array}$ & $14^{\mathrm{a}}$ & 86 & $0.71^{*}$ & - & - & - & - & - \\
\hline & - & - & - & - & - & $\begin{array}{l}\text { Everyone should be able to } \\
\text { choose whether or not to do } \\
\text { vaccinate his/her children }\end{array}$ & 15 & 93 & $0.87^{*}$ \\
\hline & - & - & - & - & - & $\begin{array}{l}\text { Everyone should be able to } \\
\text { decide which vaccines are } \\
\text { necessary for his/her children }\end{array}$ & 15 & 67 & 0.33 \\
\hline \multirow[t]{4}{*}{$\begin{array}{l}\text { Perception of the } \\
\text { pharmaceutical industry }\end{array}$} & $\begin{array}{l}\text { The pharmaceutical industry is } \\
\text { concerned above all by its financial } \\
\text { interests }\end{array}$ & 15 & 60 & 0.20 & $\begin{array}{l}\text { The pharmaceutical industry is more } \\
\text { concerned about its financial } \\
\text { interests than by public health }\end{array}$ & - & 15 & 67 & 0.33 \\
\hline & $\begin{array}{l}\text { The pharmaceutical industry follows } \\
\text { strict manufacturing procedures }\end{array}$ & 15 & 80 & $0.60^{*}$ & - & - & - & - & - \\
\hline & $\begin{array}{l}\text { The HPV vaccine is being pushed to } \\
\text { make money for pharmaceutical } \\
\text { companies } \dagger\end{array}$ & 15 & 73 & 0.47 & $\begin{array}{l}\text { The recommendation of the } \\
\text { papillomavirus mainly serves the } \\
\text { financial interests of the } \\
\text { pharmaceutical industry }\end{array}$ & - & 15 & 73 & 0.57 \\
\hline & - & - & - & - & - & $\begin{array}{l}\text { The pharmaceutical industry } \\
\text { follows rigorous procedures to } \\
\text { control the safety of vaccines }\end{array}$ & 15 & 67 & 0.33 \\
\hline \multirow{6}{*}{$\begin{array}{l}\text { Individual and group factors } \\
\text { Personal, family and/or } \\
\text { community members' } \\
\text { experience }\end{array}$} & & & & & & & & & \\
\hline & $\begin{array}{l}\text { I happened to refuse a vaccine for my } \\
\text { daughter (or choose not to get her } \\
\text { vaccinated) }\end{array}$ & 15 & 93 & $0.87^{*}$ & - & - & - & - & - \\
\hline & $\begin{array}{l}\text { I happened to refuse a vaccine for } \\
\text { myself (or choose not to get } \\
\text { vaccinated) }\end{array}$ & 15 & 87 & $0.73^{*}$ & - & - & - & - & - \\
\hline & $\begin{array}{l}\text { I know a person who fell seriously ill } \\
\text { after getting vaccinated }\end{array}$ & 15 & 87 & $0.73^{*}$ & - & - & - & - & - \\
\hline & $\begin{array}{l}\text { I know someone who became } \\
\text { seriously ill because s/he was not } \\
\text { vaccinated }\end{array}$ & 15 & 87 & $0.73^{*}$ & - & - & - & - & - \\
\hline & $\begin{array}{l}\text { Personally, I have already had } \\
\text { abnormal pap smears for which } \\
\text { treatment was needed } \\
\text { (conization/surgery) }\end{array}$ & 15 & 93 & $0.87^{*}$ & - & - & - & - & - \\
\hline
\end{tabular}




\begin{tabular}{|c|c|c|c|c|c|c|c|c|c|}
\hline \multirow[b]{2}{*}{ Factor } & \multirow[b]{2}{*}{ Initial item } & \multicolumn{3}{|c|}{ Round $1(\mathrm{n}=15)$} & \multirow[b]{2}{*}{ Reformulated item } & \multirow[b]{2}{*}{ Additional item } & \multicolumn{3}{|c|}{ Round $2(n=15)$} \\
\hline & & $\mathrm{N}$ & $\begin{array}{l}\text { \% agreement } \\
\text { for "essential" }\end{array}$ & $\begin{array}{l}\text { Content } \\
\text { Validity } \\
\text { Ratio }\end{array}$ & & & $\mathrm{n}$ & $\begin{array}{l}\% \\
\text { agreement } \\
\text { for } \\
\text { "essential" }\end{array}$ & $\begin{array}{l}\text { Content } \\
\text { Validity } \\
\text { Ratio }\end{array}$ \\
\hline \multirow[t]{7}{*}{$\begin{array}{l}\text { Beliefs, attitudes about health } \\
\text { and prevention }\end{array}$} & $\begin{array}{l}\text { Complementary medicine should be } \\
\text { subject to more scientific testing } \\
\text { before it can be accepted by } \\
\text { conventional doctors } \S\end{array}$ & 15 & 47 & -0.06 & $\begin{array}{l}\text { Alternative medicines (i.e. non- } \\
\text { conventional medicines, for example } \\
\text { phytotherapy, homeopathy, } \\
\text { naturopathy...) should be subjected } \\
\text { to more scientific studies before they } \\
\text { can be accepted by conventional } \\
\text { physicians. }\end{array}$ & - & 15 & 27 & -0.46 \\
\hline & $\begin{array}{l}\text { Complementary medicine can be } \\
\text { dangerous in that it may prevent } \\
\text { people getting proper treatment } \S\end{array}$ & 15 & 33 & -0.33 & $\begin{array}{l}\text { Alternative medicines (i.e. non- } \\
\text { conventional medicines, for example } \\
\text { phytotherapy, homeopathy, } \\
\text { naturopathy...) may be dangerous } \\
\text { as they can prevent people from } \\
\text { obtaining/accessing appropriate } \\
\text { treatment }\end{array}$ & - & $14^{\mathrm{a}}$ & 28 & -0.43 \\
\hline & $\begin{array}{l}\text { Complementary medicine should } \\
\text { only be used as a last resort when } \\
\text { conventional medicine has nothing to } \\
\text { offer } \S\end{array}$ & 15 & 67 & 0.33 & $\begin{array}{l}\text { Alternative medicines should only } \\
\text { be used as a last resort when } \\
\text { conventional medicine has nothing } \\
\text { to offer }\end{array}$ & - & $14^{\mathrm{a}}$ & 43 & -0.14 \\
\hline & $\begin{array}{l}\text { It is worthwhile trying } \\
\text { complementary medicine before } \\
\text { going to the doctor } \S\end{array}$ & 15 & 40 & -0.20 & $\begin{array}{l}\text { It is interesting to try alternative } \\
\text { medicines (i.e. non-conventional } \\
\text { medicines, for example } \\
\text { phytotherapy, homeopathy, } \\
\text { naturopathy...) before going to the } \\
\text { doctor }\end{array}$ & - & $14^{\mathrm{a}}$ & 36 & -0.29 \\
\hline & $\begin{array}{l}\text { Complementary medicine builds up } \\
\text { the body's own defenses, so leading } \\
\text { to a permanent cure } \S\end{array}$ & 15 & 80 & $0.60^{*}$ & - & - & - & - & - \\
\hline & - & - & - & - & - & $\begin{array}{l}\text { Alternative medicines (i.e.non- } \\
\text { conventional medicines, for } \\
\text { example phytotherapy, } \\
\text { homeopathy, naturopathy....) } \\
\text { can replace some vaccines }\end{array}$ & 15 & 73 & 0.57 \\
\hline & - & - & - & - & - & $\begin{array}{l}\text { I prefer that my daughter } \\
\text { develops naturally defences } \\
\text { against papillomavirus rather } \\
\text { than by vaccination }\end{array}$ & 15 & 80 & $0.60^{*}$ \\
\hline \multirow[t]{4}{*}{ Knowledge/awareness } & $\begin{array}{l}\text { Have you ever searched for } \\
\text { information on the HPV vaccine in the } \\
\text { past? }\end{array}$ & $14^{\mathrm{a}}$ & 100 & $\mathbf{1}^{*}$ & - & - & - & - & - \\
\hline & $\begin{array}{l}\text { (If already researched information) } \\
\text { Cite the } 3 \text { most consulted sources of } \\
\text { information: Attending physician/ } \\
\text { Other health professional/Internet/ } \\
\text { Family/ Books/Print media/Other }\end{array}$ & 15 & 87 & $0.73^{*}$ & - & - & - & - & - \\
\hline & $\begin{array}{l}\text { (If used the internet) How did you use } \\
\text { the internet? I went to forums/I } \\
\text { visited blogs/I looked at social media/ } \\
\text { I consulted news websites/Other }\end{array}$ & 15 & 87 & $0.73^{*}$ & - & - & - & - & - \\
\hline & $\begin{array}{l}\text { (If consulted information sites) } \\
\text { Which website? Santé Publique } \\
\text { France/ Vaccination info service/ }\end{array}$ & 15 & 73 & 0.47 & $\begin{array}{l}\text { (If consulted information sites) } \\
\text { Which website? Santé Publique } \\
\text { France /Vaccination info service/ }\end{array}$ & - & 15 & 80 & $0.60^{*}$ \\
\hline
\end{tabular}


Table 2 (continued)

\begin{tabular}{|c|c|c|c|c|c|c|c|c|c|}
\hline \multirow[b]{2}{*}{ Factor } & \multirow[b]{2}{*}{ Initial item } & \multicolumn{3}{|c|}{ Round $1(\mathrm{n}=15)$} & \multirow[b]{2}{*}{ Reformulated item } & \multirow[b]{2}{*}{ Additional item } & \multicolumn{3}{|c|}{ Round $2(\mathrm{n}=15)$} \\
\hline & & $\mathrm{N}$ & $\begin{array}{l}\text { \% agreement } \\
\text { for "essential" }\end{array}$ & $\begin{array}{l}\text { Content } \\
\text { Validity } \\
\text { Ratio }\end{array}$ & & & $\mathrm{n}$ & $\begin{array}{l}\% \\
\text { agreement } \\
\text { for } \\
\text { "essential" }\end{array}$ & $\begin{array}{l}\text { Content } \\
\text { Validity } \\
\text { Ratio }\end{array}$ \\
\hline & $\begin{array}{l}\text { Doctissimo, Allodocteur/Pourquoi } \\
\text { docteur/Infovac/ France Info/Le } \\
\text { Monde/Le Figaro/Alter Info/ } \\
\text { Alternative Health/Initiative } \\
\text { citoyenne/Other }\end{array}$ & & & & $\begin{array}{l}\text { Doctissimo, Allodocteur/Pourquoi } \\
\text { docteur/Infovac/France Info / Le } \\
\text { Monde/Le Figaro/Alter Info/ } \\
\text { Alternative Health/Initiative } \\
\text { citoyenne/ Mesvaccins.net/INCa/ } \\
\text { other }\end{array}$ & & & & \\
\hline & $\begin{array}{l}\text { (If has already searched for } \\
\text { information) After having had all this } \\
\text { information, were you able to take a } \\
\text { decision regarding the HPV } \\
\text { vaccination? }\end{array}$ & 15 & 87 & $0.73^{*}$ & - & - & - & - & - \\
\hline & HPV can cause HIV/AIDS 柿 & 15 & 53 & 0.07 & - & - & 15 & 47 & -0.06 \\
\hline & $\begin{array}{l}\text { The HPV vaccine requires only one } \\
\text { dose } \dagger \dagger\end{array}$ & 15 & 53 & 0.07 & - & - & 15 & 40 & -0.20 \\
\hline & $\begin{array}{l}\text { The HPV vaccines offer protection } \\
\text { against all sexually transmitted } \\
\text { infections } \dagger \dagger\end{array}$ & 15 & 67 & 0.33 & - & - & 15 & 87 & $0.73^{*}$ \\
\hline & $\begin{array}{l}\text { The HPV vaccines are most effective if } \\
\text { given to people who've never had sex } \\
\dagger \dagger\end{array}$ & 15 & 73 & 0.47 & - & - & 15 & 87 & $0.73^{*}$ \\
\hline & $\begin{array}{l}\text { Someone who has had the HPV } \\
\text { vaccine cannot develop cervical } \\
\text { cancer } \dagger \dagger\end{array}$ & 15 & 67 & 0.33 & $\begin{array}{l}\text { A person who has been vaccinated } \\
\text { against HPV can still develop } \\
\text { cervical cancer }\end{array}$ & - & 15 & 80 & $0.60^{*}$ \\
\hline & $\begin{array}{l}\text { The HPV vaccines offer protection } \\
\text { against most cervical cancers } \dagger \dagger\end{array}$ & 15 & 67 & 0.33 & - & - & 15 & 73 & 0.57 \\
\hline & $\begin{array}{l}\text { The HPV vaccines offer protection } \\
\text { against genital warts } \dagger \dagger\end{array}$ & 15 & 87 & $0.73^{*}$ & & & & & \\
\hline & $\begin{array}{l}\text { Girls who have had the HPV vaccine } \\
\text { do not need a Pap test when they are } \\
\text { odler } \dagger \dagger\end{array}$ & 15 & 71 & 0.33 & $\begin{array}{l}\text { Girls who have been vaccinated } \\
\text { against HPV need Pap test when they } \\
\text { are older }\end{array}$ & - & 15 & 87 & $0.73^{*}$ \\
\hline & $\begin{array}{l}\text { The HPV vaccine protects (you) from } \\
\text { every type of HPV } \dagger \dagger\end{array}$ & 15 & 53 & 0.07 & - & - & $14^{\mathrm{a}}$ & 64 & 0.43 \\
\hline & $\begin{array}{l}\text { You can cure HPV by getting the HPV } \\
\text { vaccine } \dagger \dagger\end{array}$ & 15 & 73 & 0.47 & - & - & 15 & 80 & $0.60^{*}$ \\
\hline & HPV is very rare $\dagger \dagger$ & 15 & 80 & $0.60^{*}$ & - & - & - & - & - \\
\hline & $\begin{array}{l}\text { HPV always has visible signs or } \\
\text { symptoms } \dagger \dagger\end{array}$ & 15 & 60 & 0.20 & $\begin{array}{l}\text { There are always signs or symptoms } \\
\text { visible in case of papillomavirus } \\
\text { infection }\end{array}$ & - & 15 & 67 & 0.33 \\
\hline & Men cannot get HPV $\dagger \dagger$ & 15 & 87 & $0.73^{*}$ & - & - & - & - & - \\
\hline & $\begin{array}{l}\text { A person could have HPV for many } \\
\text { years without knowing it } \dagger \dagger\end{array}$ & 15 & 86 & $0.60^{*}$ & - & - & - & - & - \\
\hline & $\begin{array}{l}\text { Having sex at an early age increases } \\
\text { the risk of getting HPV †† }\end{array}$ & 15 & 67 & 0.33 & - & - & $14^{\mathrm{a}}$ & 78 & $0.57^{*}$ \\
\hline & $\begin{array}{l}\text { HPV can be transmitted through oral } \\
\text { sex } \dagger \dagger\end{array}$ & 15 & 80 & $0.60^{*}$ & - & - & - & - & - \\
\hline & HPV can cause cancer of the penis $\dagger \dagger$ & 15 & 67 & 0.33 & - & - & 15 & 73 & 0.57 \\
\hline & $\begin{array}{l}\text { HPV infections always lead to health } \\
\text { problems } \dagger \dagger\end{array}$ & $14^{\mathrm{a}}$ & 43 & -0.14 & - & - & 15 & 53 & 0.07 \\
\hline & HPV can cause oral cancer $\dagger \dagger$ & $13^{\mathrm{b}}$ & 70 & 0.36 & - & - & 15 & 80 & $0.60^{*}$ \\
\hline
\end{tabular}




\begin{tabular}{|c|c|c|c|c|c|c|c|c|c|}
\hline \multirow[b]{2}{*}{ Factor } & \multirow[b]{2}{*}{ Initial item } & \multicolumn{3}{|c|}{ Round $1(\mathrm{n}=15)$} & \multirow[b]{2}{*}{ Reformulated item } & \multirow[b]{2}{*}{ Additional item } & \multicolumn{3}{|c|}{ Round $2(\mathrm{n}=15)$} \\
\hline & & $\mathrm{N}$ & $\begin{array}{l}\text { \% agreement } \\
\text { for "essential" }\end{array}$ & $\begin{array}{l}\text { Content } \\
\text { Validity } \\
\text { Ratio }\end{array}$ & & & $\mathrm{n}$ & $\begin{array}{l}\% \\
\text { agreement } \\
\text { for } \\
\text { "essential" }\end{array}$ & $\begin{array}{l}\text { Content } \\
\text { Validity } \\
\text { Ratio }\end{array}$ \\
\hline \multirow[t]{3}{*}{$\begin{array}{l}\text { Health system and providers- } \\
\text { trust and personal } \\
\text { experience }\end{array}$} & $\begin{array}{l}\text { Please indicate to what extent you } \\
\text { trust the following sources to tell the } \\
\text { truth about vaccinations: } \\
\text { pharmaceutical } \\
\text { industry/government/your attending } \\
\text { physician/physicians in general/ } \\
\text { pharmacists/other health } \\
\text { professionals/scientific researchers / } \\
\text { mainstream media/alternative media } \\
\text { (media that convey information } \\
\text { alternatives to the commercial mass } \\
\text { media and state media, e.g. Agoravox, } \\
\text { Altlantic, and Alterinfo) }\end{array}$ & 15 & 93 & $0.87^{*}$ & - & - & - & - & - \\
\hline & $\begin{array}{l}\text { I know someone in my circle who has } \\
\text { already been victim of a medical error }\end{array}$ & 15 & 53 & 0.07 & - & - & 15 & 33 & -0.28 \\
\hline & $\begin{array}{l}\text { I consider that I have already been } \\
\text { victim of a medical error }\end{array}$ & 15 & 53 & 0.07 & - & - & 15 & 33 & -0.28 \\
\hline \multirow[t]{14}{*}{$\begin{array}{l}\text { Risk/benefit (perceived, } \\
\text { heuristic) }\end{array}$} & $\begin{array}{l}\text { Giving my daughter the HPV vaccine } \\
\text { would be like performing an } \\
\text { experiment on her } \dagger\end{array}$ & 15 & 27 & -0.46 & - & - & 15 & 20 & -0.57 \\
\hline & $\begin{array}{l}\text { The HPV vaccine may lead to long- } \\
\text { term health problems } \dagger\end{array}$ & 15 & 80 & $0.60^{*}$ & - & - & $14^{\mathrm{a}}$ & 50 & 0 \\
\hline & $\begin{array}{l}\text { There has not been enough research } \\
\text { done on the HPV vaccine } \dagger\end{array}$ & 15 & 93 & $0.87^{*}$ & - & - & - & - & - \\
\hline & The HPV vaccine is unsafe $\dagger$ & 15 & 80 & $0.60^{*}$ & - & - & - & - & - \\
\hline & The HPV vaccine has many benefits $\dagger$ & 15 & 53 & 0.07 & - & - & $14^{\mathrm{a}}$ & 50 & 0 \\
\hline & $\begin{array}{l}\text { The HPV vaccine will protect my } \\
\text { daughter's sexual health } \dagger\end{array}$ & 15 & 74 & 0.46 & $\begin{array}{l}\text { Vaccinating my daughter against } \\
\text { HPV will help protect her against i } \\
\text { sexually transmitted infections }\end{array}$ & - & 15 & 80 & $0.60^{*}$ \\
\hline & $\begin{array}{l}\text { The HPV vaccine is effective in } \\
\text { preventing } \mathrm{HPV}_{\dagger}\end{array}$ & 15 & 80 & $0.60^{*}$ & - & - & - & - & - \\
\hline & $\begin{array}{l}\text { The HPV vaccine is effective in } \\
\text { preventing genital warts } \dagger\end{array}$ & 15 & 80 & $0.60^{*}$ & - & - & - & - & - \\
\hline & $\begin{array}{l}\text { The HPV vaccine is effective in } \\
\text { preventing HPV-related cancers } \dagger\end{array}$ & 15 & 71 & 0.42 & - & & $14^{\mathrm{a}}$ & 93 & $0.86^{*}$ \\
\hline & - & - & - & - & - & $\begin{array}{l}\text { Without the HPV vaccine, my } \\
\text { daughter would be at risk of } \\
\text { getting HPV later in life } \dagger\end{array}$ & 15 & 53 & 0.07 \\
\hline & - & - & - & - & - & $\begin{array}{l}\text { Without the HPV vaccine, my } \\
\text { daughter would be at risk of } \\
\text { getting genital wartsl later in } \\
\text { life } \dagger\end{array}$ & 15 & 53 & 0.07 \\
\hline & - & - & - & - & - & $\begin{array}{l}\text { Without the HPV vaccine, my } \\
\text { daughter would be at risk of } \\
\text { getting an HPV related cancer } \\
\text { later in life } \dagger\end{array}$ & 15 & 67 & 0.33 \\
\hline & - & - & - & - & - & $\begin{array}{l}\text { The use of a condom prevents } \\
\text { the transmission of HPV } \\
\text { infection }\end{array}$ & 15 & 87 & $0.73^{*}$ \\
\hline & - & - & - & - & - & $\begin{array}{l}\text { The pap smear is sufficient to } \\
\text { prevent cervical cancer }\end{array}$ & $14^{\mathrm{a}}$ & 86 & $0.85^{*}$ \\
\hline
\end{tabular}


Table 2 (continued)

\begin{tabular}{|c|c|c|c|c|c|c|c|c|c|}
\hline \multirow[b]{2}{*}{ Factor } & \multirow[b]{2}{*}{ Initial item } & \multicolumn{3}{|c|}{ Round $1(n=15)$} & \multirow[b]{2}{*}{ Reformulated item } & \multirow[b]{2}{*}{ Additional item } & \multicolumn{3}{|c|}{ Round $2(\mathrm{n}=15)$} \\
\hline & & $\mathrm{N}$ & $\begin{array}{l}\text { \% agreement } \\
\text { for "essential" }\end{array}$ & $\begin{array}{l}\text { Content } \\
\text { Validity } \\
\text { Ratio }\end{array}$ & & & $\mathrm{n}$ & $\begin{array}{l}\% \\
\text { agreement } \\
\text { for } \\
\text { "essential" }\end{array}$ & $\begin{array}{l}\text { Content } \\
\text { Validity } \\
\text { Ratio }\end{array}$ \\
\hline & - & - & - & - & - & $\begin{array}{l}\text { HPV can be passed on during } \\
\text { sexual intercourse } \dagger \dagger\end{array}$ & 15 & 67 & 0.33 \\
\hline & - & - & - & - & - & $\begin{array}{l}\text { Having many sexual partners } \\
\text { increases the risk of getting } \\
\text { HPV } \dagger \dagger\end{array}$ & 15 & 67 & 0.33 \\
\hline \multirow{6}{*}{$\begin{array}{l}\text { Immunisation as a social } \\
\text { norm vs. not needed/ } \\
\text { harmful }\end{array}$} & $\begin{array}{l}\text { My friends are getting their daughter } \\
\text { vaccinated with the HPV vaccine } \dagger\end{array}$ & $14^{\mathrm{a}}$ & 93 & $0.87^{*}$ & - & - & - & - & - \\
\hline & $\begin{array}{l}\text { Most }{ }^{c} \text { girls around my daughter 's age } \\
\text { are getting vaccinated for HPV } \dagger\end{array}$ & $14^{\mathrm{a}}$ & 100 & $\mathbf{1}^{*}$ & - & - & - & - & - \\
\hline & $\begin{array}{l}\text { It is expected of me that I should } \\
\text { vaccinate my daughter against } \mathrm{HPV} \dagger\end{array}$ & $14^{\mathrm{a}}$ & 57 & 0.14 & - & - & $14^{\mathrm{a}}$ & 43 & -0.14 \\
\hline & 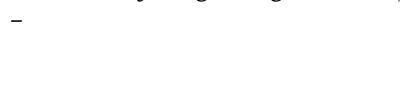 & - & - & - & - & $\begin{array}{l}\text { Most of my friends think } \\
\text { vaccinating my daughter } \\
\text { against HPV is a good idea } \dagger\end{array}$ & $14^{\mathrm{a}}$ & 43 & -0.14 \\
\hline & - & - & - & - & - & $\begin{array}{l}\text { Doctors/health care providers } \\
\text { believe vaccinating girls } \\
\text { against HPV is a good idea } \dagger\end{array}$ & 15 & 93 & $0.87^{*}$ \\
\hline & - & - & - & - & - & $\begin{array}{l}\text { My family thinks it is a good } \\
\text { idea to vaccinate my -daughter } \\
\text { against } \mathrm{HPV} \dagger\end{array}$ & 15 & 60 & 0.28 \\
\hline \multicolumn{10}{|c|}{ Vaccine/vaccination specific factors } \\
\hline $\begin{array}{l}\text { Introduction of a new vaccine } \\
\text { or new formulation or a } \\
\text { newrecommendation for } \\
\text { an existing vaccine }\end{array}$ & The HPV vaccine is too new $\dagger$ & 15 & 74 & 0.46 & $\begin{array}{l}\text { The HPV vaccine is too recent so we } \\
\text { can know if it's safe and reliable }\end{array}$ & - & 15 & 80 & $0.60^{*}$ \\
\hline \multirow[t]{4}{*}{$\begin{array}{l}\text { Design of vaccination } \\
\text { program/Mode of delivery }\end{array}$} & $\begin{array}{l}\text { It is complicated to vaccinate my } \\
\text { daughter against HPV because it } \\
\text { requires } 3 \text { steps: see the doctor for } \\
\text { the vaccine prescription, go buy the } \\
\text { vaccine at the pharmacy, and return } \\
\text { to the doctor for the vaccine injection }\end{array}$ & 15 & 80 & $0.60^{*}$ & - & - & - & - & - \\
\hline & $\begin{array}{l}\text { It would be easier to vaccinate my } \\
\text { daughter if the pharmacist could } \\
\text { perform the injection }\end{array}$ & 15 & 67 & 0.33 & - & - & $14^{\mathrm{a}}$ & 71 & 0.43 \\
\hline & $\begin{array}{l}\text { It would be easier to vaccinate my } \\
\text { daughter if the doctor had vaccines at } \\
\text { his office for vaccinating my daughter } \\
\text { the same day }\end{array}$ & 15 & 80 & $0.60^{*}$ & - & - & - & - & - \\
\hline & - & - & - & - & - & $\begin{array}{l}\text { It would be easier to get my } \\
\text { daughter vaccinated against } \\
\text { HPV if this vaccination was } \\
\text { carried out at school } \\
\text { (instruction: ask the question } \\
\text { in the past if the vaccine has } \\
\text { been administered) }\end{array}$ & 15 & 73 & 0.57 \\
\hline \multirow[t]{3}{*}{$\begin{array}{l}\text { Reliability and/or source of } \\
\text { supply of vaccine and/or } \\
\text { vaccination equipment }\end{array}$} & $\begin{array}{l}\text { I am concerned about the quality of } \\
\text { the vaccines because they can be } \\
\text { manufactured elsewhere than in } \\
\text { Europe }\end{array}$ & 15 & 60 & 0.20 & - & - & 15 & 47 & -0.06 \\
\hline & $\begin{array}{l}\text { I trust the pharmacists to keep } \\
\text { vaccines cold as required }\end{array}$ & 15 & 47 & -0.06 & - & - & 15 & 40 & -0.20 \\
\hline & I do not find it normal that some & 15 & 67 & 0.33 & - & - & 15 & 60 & 0.28 \\
\hline
\end{tabular}




\begin{tabular}{|c|c|c|c|c|c|c|c|c|c|}
\hline \multirow[b]{2}{*}{ Factor } & \multirow[b]{2}{*}{ Initial item } & \multicolumn{3}{|c|}{ Round $1(\mathrm{n}=15)$} & \multirow[b]{2}{*}{ Reformulated item } & \multirow[b]{2}{*}{ Additional item } & \multicolumn{3}{|c|}{ Round $2(\mathrm{n}=15)$} \\
\hline & & $\mathrm{N}$ & $\begin{array}{l}\text { \% agreement } \\
\text { for "essential" }\end{array}$ & $\begin{array}{l}\text { Content } \\
\text { Validity } \\
\text { Ratio }\end{array}$ & & & $\mathrm{n}$ & $\begin{array}{l}\% \\
\text { agreement } \\
\text { for } \\
\text { "essential" }\end{array}$ & $\begin{array}{l}\text { Content } \\
\text { Validity } \\
\text { Ratio }\end{array}$ \\
\hline \multirow[t]{3}{*}{ Vaccination schedule } & $\begin{array}{l}\text { If the HPV vaccine was important, it } \\
\text { would have been made mandatory }\end{array}$ & $14^{\mathrm{a}}$ & 86 & $0.71^{*}$ & - & - & - & - & - \\
\hline & $\begin{array}{l}\text { The HPV vaccine has not been made } \\
\text { mandatory because it is risky }\end{array}$ & $14^{\mathrm{a}}$ & 73 & 0.47 & - & - & 15 & 80 & $0.60^{*}$ \\
\hline & $\begin{array}{l}\text { I think my daughter is too young to } \\
\text { be vaccinated against HPV }\end{array}$ & 15 & 87 & $0.73^{*}$ & - & - & - & - & - \\
\hline Costs & $\begin{array}{l}\text { I think that the HPV vaccine is too } \\
\text { expensive for my budget }\end{array}$ & 15 & 73 & 0.47 & $\begin{array}{l}\text { I think the HPV vaccine is too } \\
\text { expensive for me }\end{array}$ & & 15 & 73 & 0.47 \\
\hline \multirow{4}{*}{$\begin{array}{l}\text { The strength of the } \\
\text { recommendation and/or } \\
\text { knowledge base } \\
\text { and/or attitude of } \\
\text { healthcare professionals }\end{array}$} & $\begin{array}{l}\text { Has a doctor or another health } \\
\text { professional ever recommended that } \\
\text { you vaccinate your daughter against } \\
\text { HPV? }\end{array}$ & 15 & 100 & $1^{*}$ & - & - & - & - & - \\
\hline & $\begin{array}{l}\text { Have you asked any questions to your } \\
\text { attending doctor about HPV } \\
\text { vaccines? }\end{array}$ & 15 & 93 & $0.87^{*}$ & - & - & - & - & - \\
\hline & $\begin{array}{l}\text { (If has already asked questions) Were } \\
\text { you satisfied with his/her answers? }\end{array}$ & 15 & 87 & $0.73^{*}$ & - & - & - & - & - \\
\hline & - & - & - & - & - & $\begin{array}{l}\text { (If has already asked questions } \\
\text { of her doctor concerning } \\
\text { vaccination against HPV) Was } \\
\text { your attending physician } \\
\text { hesitant regarding this } \\
\text { vaccine? }\end{array}$ & 15 & 100 & $1^{*}$ \\
\hline
\end{tabular}

${ }^{2}$ CVR for 14 respondents $=0.57$

CVR for 13 respondents $=0.54$

"We replaced the term "other" used in the original instrument by "most".

$\dagger$ Items from the HPV Attitudes and Beliefs Scale (19 items submitted in Round 1 and 6 items submitted in Round 2).

† Items from the HPV General Knowledge and the HPV Vaccination Knowledge Scales (19 items submitted in Round 1 and 3 items submitted in Round 2).

$\S$ Items from the Holistic Complementary and Alternative Medicine Questionnaire (5 items submitted in Round 1)

I Items from the Vaccine Confidence Project (1 item submitted in Round 1 ).

* Response over the predefined threshold according to Lawshe's formula.

${ }^{* *}$ Mediator was an antidiabetic drug given as a slimming agent, leading to national scandal in France.

Bold values indicate content validity ratio above the threshold. 


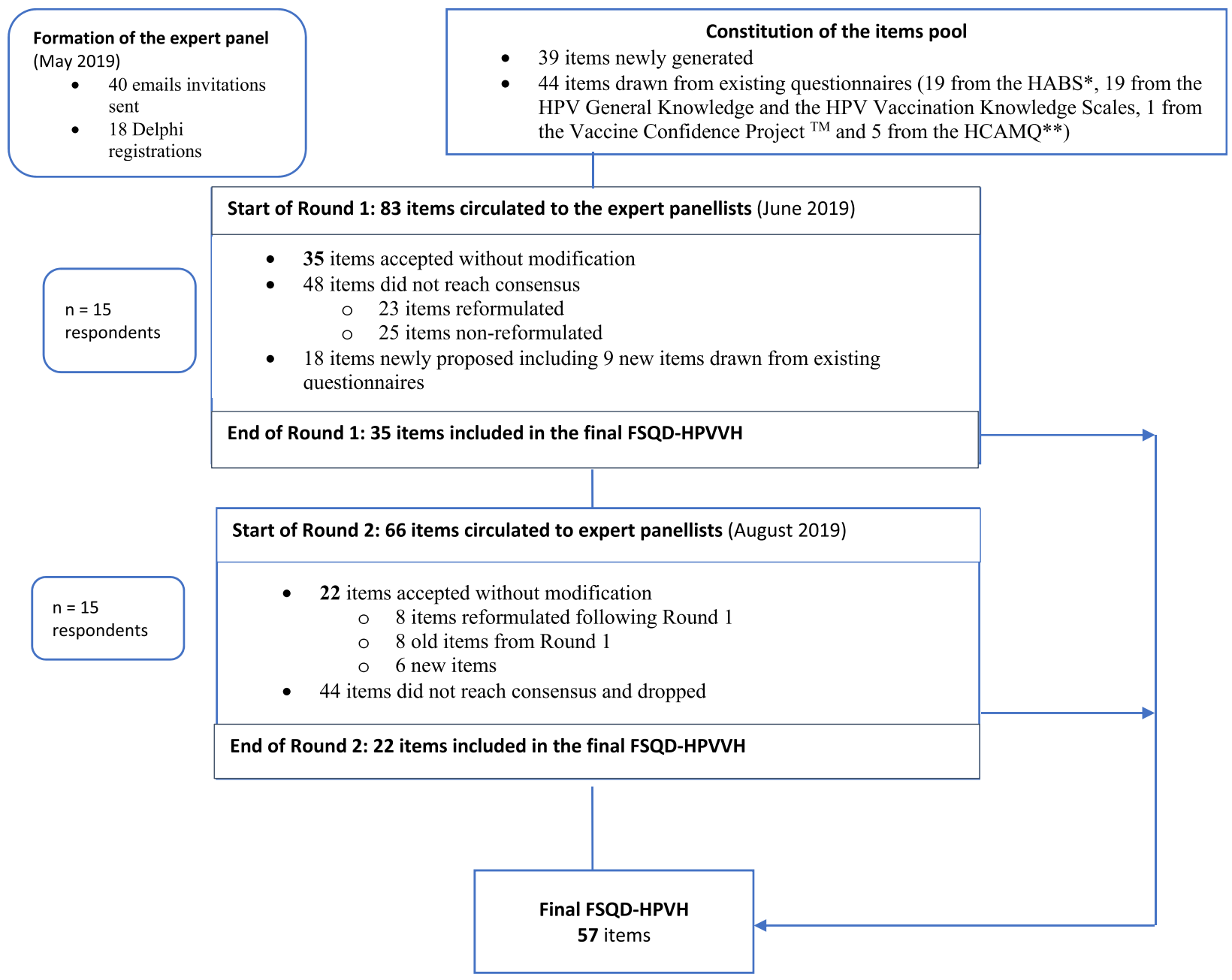

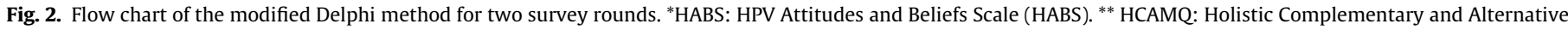
Medicine Questionnaire.

\subsection{Round 2}

In Round 2, 66 items were submitted to the expert panel. Of those, 48 were items that did not reach consensus at Round 1 and were recirculated either as initially worded $(n=25,52 \%)$ or after rewording ( $n=23,48 \%$ ), and 18 were new items. Among the new items, 9 were drawn from existing instruments (one item about "Knowledge/awareness" drawn from the HPV General Knowledge and HPV Vaccination Knowledge Scales [33], 3 items about "Immunisation as a social norm vs. not needed harmful" drawn from the HABS (32), and 5 items about "Risk/benefit (perceived/heuristic)" drawn from the HABS $(n=3)$ and from the HPV General Knowledge and HPV Vaccination Knowledge Scales ( $n=2)$ [33]); the remaining were developed by the scientific committee (Table 2, Fig. 2). In total, consensus was reached on 22 items (33\%). The analysis of the CVR of the individual items is shown in Table 2.

The final version of the survey instrument will include 57 items (Fig. 2 and Supplemental File 1): 10 items in the category "Contextual influences", 37 items in the category "Individual and group influences", and 10 items in the category "Vaccine/vaccination-spe cific issues".

\section{Discussion}

In this study, we developed a survey instrument specifically intended to evaluate HPV vaccine hesitancy among mothers of age-vaccination daughters in France. Within two rounds of a reactive Delphi methodology that took 12 weeks from preparation to conclusion, we generated a pool of items and consulted a panel of 15 experts who helped develop and validate a list of questions that reflect the many factors identified in the SAGE Working Group Determinants of Vaccine Hesitancy Matrix and that should now be applied to a survey of HPV vaccination vaccine hesitancy among mothers in France.

This study builds on the limited literature to date about how to measure the determinants of HPV vaccine hesitancy. Before starting this exercise, we had found only tools focusing on partial aspects of the factors contributing to vaccine hesitancy, e.g., the Carolina HPV immunization attitudes and beliefs scale (CHIAS) [41] and HABS [32], but none looking at determinants comprehensively. The domains covered by the FSQD-HPVH that the abovementioned tools do not include are essentially those that fall under "Contextual factors", for example, "Historical influences", "Politics/ policies" and "Communication and media environment". The other domains not covered by existing questionnaires include the "Strengths of the recommendations and/or knowledge base and/ or attitudes of healthcare professionals" and "Design of vaccination program/mode of delivery". This study is novel in considering using the SAGE Working Group Determinants of Vaccine Hesitancy Matrix. This matrix has been used to classify the data of the Annual WHO/UNICEF JRF (which are collected globally across WHO Member States to monitor vaccine hesitancy) [42], but not as a data col- 
lection tool. We hope the current study will stimulate further use of this matrix to investigate vaccine hesitancy related to other vaccines or settings.

We constructed a questionnaire with the most content-valid items. It appeared that only $42 \%$ of the items were deemed representative of the construct (factor) they intended to measure at Round 1 . This finding emphasizes the relevance of including the perspectives of a multidisciplinary panel of experts. However, some of the items could be selected after rewording ( $n=8 / 23$, $35 \%$ ). Each factor is represented by at least one item, except "Reliability and/or source of supply of vaccine and/or vaccination equipment" and "Costs", which ended up without any item.

The main strengths of our study include the composition of a multidisciplinary and multi-stakeholder panel of experts and the rigorous multistage quantitative analysis of their responses. As vaccine hesitancy is a complex, multifaceted phenomenon, the problem needs to be examined in a multidisciplinary manner. An excellent retention rate (100\%) was achieved in Round 2, avoiding the risk of response bias. However, some limitations need to be acknowledged. First, the length of the final questionnaire might be challenging from a practical point of view. In a subsequent study, we aim to propose a shortened version based on factor analysis of the data collected through this questionnaire. Second, the sample size of the panel of experts was small, although it falls within the range recommended in the literature, and the calculation of the consensus criterion was weighted by the number of respondents. Third, we only performed the a priori-planned two rounds of Delphi survey. There is a delicate trade-off between the number of rounds and the risk of attrition, and it turned out that no modification in terms of rewording was required following Round 2, since the experts did not suggest any reformulations for the items that did not meet consensus. In addition, three factors ("Communication and media environment", "Perception of the pharmaceutical industry", "Health system and providers-trust and personal experience") ended up with only one item. Although single-item measures for each facet of multifaceted constructs have been suggested in the literature [43], these are often considered to compromise on reliability. Finally, the questionnaire was designed to target only the mothers as they often have the main decision-making power with regard to the HPV vaccination [44-46]. Adaptation of the item "Personally, I have already had abnormal pap smears for which treatment was needed (conization/surgery)" would be required it the questionnaire is to be administered to fathers. Finally, the FSQDHPVH was designed to be administered to the French population, with reference to the French health system and culture. However, our approach could provide a reference for other settings. The FSQD-HPVH has not yet been pilot-tested, but it is intended to aid in the evaluation of HPV vaccine hesitancy in France through administration to a large sample of mothers, which will, in turn, allow further validation.

\section{Conclusion}

In conclusion, 57 items of FSQD-HPVH with good content validity were developed in this study in preparation of a thorough evaluation of HPV vaccine hesitancy in France. Unlike other existing tools, the FSQD-HPVH is the first to comprehensively consider all factors that may influence HPV vaccine hesitancy, the first step towards an evidence-based approach to curbing the low HPV vaccination rates in France.

\section{Author's contributions}

FD has participated in the design of the study, the generation of Delphi items, the data analysis, the redaction of the manuscript, and the revision process. PC and OL have participated in the design of the study, the generation of Delphi items, and the revision process. PM has participated in the redaction of the manuscript and the revision process. All authors have approved the final manuscript. All members of the FSQD-HPVH study group have participated in the Delphi procedure.

\section{Funding}

Financial support for the study was provided by a PhD fellowship from the French National Institute of Cancer awarded to FD. This fellowship has been used to support the development of the study design, data collection, data analysis, and manuscript preparation.

\section{Declaration of Competing Interest}

The authors declare the following financial interests/personal relationships which may be considered as potential competing interests: [Fadia Dib declares that MSD vaccines have covered registration fees, transport and accommodation costs for attendance to a conference. Philippe Mayaud, Odile Launay and Pierre Chauvin declare no conflict of interest.]

\section{Appendix A. Supplementary material}

Supplementary data to this article can be found online at https://doi.org/10.1016/j.vaccine.2020.07.027.

\section{References}

[1] 1. Wellcome Global Monitor 2018 | Wellcome [Internet]. [cited 2019 Aug 14]. Available from: https://wellcome.ac.uk/reports/wellcome-global-monitor/ 2018.

[2] 2. calendrier_vaccinal_mars_2019.pdf [Internet]. [cited 2019 Dec 10]. Available from: https://solidarites-sante.gouv.fr/IMG/pdf/calendrier_vaccinal_ mars_2019.pdf.

[3] 3. Vacciner tous les garçons contre les papillomavirus ? La HAS met en consultation publique un projet de recommandation vaccinale [Internet] Haute Autorité de Santé. [cited 2019 Dec 10]. Available from: https://www.hassante.fr/jcms/p_3116003/fr/vacciner-tous-les-garcons-contre-les-papillomavirusla-has-met-en-consultation-publique-un-projet-de-recommandation-vaccinale.

[4] 4. cs2019.pdf [Internet]. [cited 2019 Dec 10]. Available from: https://drees.solidarites-sante.gouv.fr/IMG/pdf/cs2019.pdf.

[5] Grimaldi-Bensouda L, Rossignol M, Koné-Paut I, Krivitzky A, Lebrun-Frenay C, Clet J, et al. Risk of autoimmune diseases and human papilloma virus (HPV) vaccines: Six years of case-referent surveillance. J Autoimmun. 2017 May; 79:84-90.

[6] Andrews N, Stowe J, Miller E. No increased risk of Guillain-Barré syndrome after human papilloma virus vaccine: A self-controlled case-series study in England. Vaccine 2017;35(13):1729-32.

[7] Hviid A, Svanström H, Scheller NM, Grönlund O, Pasternak B, ArnheimDahlström L. Human papillomavirus vaccination of adult women and risk of autoimmune and neurological diseases. J Intern Med. 2018 Feb;283 (2):154-65.

[8] 8. WER9219.pdf [Internet]. [cited 2019 Sep 13]. Available from: https://apps. who.int/iris/bitstream/handle/10665/255353/WER9219.pdf;jsessionid= 2386AFE046ADC8B4D0B996344595CFAA? sequence=1).

[9] Fonteneau L, Barret AS, Lévy-Bruhl D. Évolution de la couverture vaccinale du vaccin contre le papillomavirus en France - 2008-2018. Bull Epidémiol Hebd. 2019;(22-23):424-30. Available from: http://beh.santepubliquefrance.fr/beh/ 2019/22-23/2019_22-23_3.htm.

[10] 10. Plan Cancer 2014-2019 - Ref : PLANKPNRT14 | Institut National Du Cancer [Internet]. [cited 2018 Jan 28]. Available from: http://www.e-cancer.fr/ Expertises-et-publications/Catalogue-des-publications/Plan-Cancer-20142019.

[11] 11. DEU.pdf [Internet]. [cited 2019 Dec 2]. Available from: https://www. hpvcentre.net/statistics/reports/DEU.pdf?t=1575294458729.

[12] 12. GBR.pdf [Internet]. [cited 2019 Dec 2]. Available from: https://hpvcentre. net/statistics/reports/GBR.pdf?t=1575295648659.

[13] Le Plan cancer 2009-2013 - Les Plans cancer de 2003 à 2013 | Institut National Du Cancer [Internet]. [cited 2018 Jan 28]. Available from: http://www.ecancer.fr/Plan-cancer/Les-Plans-cancer-de-2003-a-2013/Le-Plan-cancer2009-2013.

[14] Guthmann J-P, Pelat C, Célant N, Parent du Chatelet I, Duport N, Rochereau T, et al. Socioeconomic inequalities to accessing vaccination against human 
papillomavirus in France: Results of the Health, Health Care and Insurance Survey, 2012. Rev Epidemiol Sante Publique 2017;65(2):109-17.

[15] Héquet D, Rouzier R. Determinants of geographic inequalities in HPV vaccination in the most populated region of France. Grce M, editor. PLOS ONE [Internet]. 2017 Mar 3 [cited 2018 Jan 22];12(3):e0172906. Available from: http://dx.plos.org/10.1371/journal.pone.0172906.

[16] Haesebaert J, Lutringer-Magnin D, Kalecinski J, Barone G, Jacquard A-C, Leocmach Y, et al. Disparities of perceptions and practices related to cervical cancer prevention and the acceptability of HPV vaccination according to educational level in a French cross-sectional survey of 18-65 years old women. PLoS ONE 2014;9(10).

[17] Haesebaert J, Lutringer-Magnin D, Kalecinski J, Barone G, Jacquard A-C, Régnier $\mathrm{V}$, et al. French women's knowledge of and attitudes towards cervical cancer prevention and the acceptability of HPV vaccination among those with 14-18 year old daughters: a quantitative-qualitative study. BMC Public Health. 2012 Nov:27(12):1034.

[18] Lee Mortensen G, Adam M, Idtaleb L. Parental attitudes towards male human papillomavirus vaccination: a pan-European cross-sectional survey. BMC Public Health [Internet] 2015;15(1). http://bmcpublichealth.biomedcentral.com/ articles/10.1186/s12889-015-1863-6.

[19] Verger P, Fressard L, Collange F, Gautier A, Jestin C, Launay O, et al. Vaccine Hesitancy Among General Practitioners and Its Determinants During Controversies: A National Cross-sectional Survey in France. EBioMedicine 2015;2 (8):891-7. http://linkinghub.elsevier.com/retrieve/pii/S2352396415300475.

[20] MacDonald NE. SAGE Working Group on Vaccine Hesitancy. Vaccine hesitancy: Definition, scope and determinants. Vaccine 2015;33(34):4161-4.

[21] Rey D, Fressard L, Cortaredona S, Bocquier A, Gautier A, Peretti-Watel P, et al. Vaccine hesitancy in the French population in 2016, and its association with vaccine uptake and perceived vaccine risk-benefit balance. Euro Surveill Bull Eur Sur Mal Transm Eur. Commun Dis Bull. 2018;Apr:23(17).

[22] Larson HJ, Jarrett C, Schulz WS, Chaudhuri M, Zhou Y, Dube E, et al. Measuring vaccine hesitancy: The development of a survey tool. Vaccine [Internet] 2015;33 (34):4165-75. http://linkinghub.elsevier.com/retrieve/pii/S0264410X15005010.

[23] REPORT OF THE SAGE WORKING GROUP ON VACCINE HESITANCY [Internet]. [cited 2018 Jan 28]. Available from: http://webcache.googleusercontent.com/ search?q=cache:BBHHbg-mCiMJ:www.who.int/immunization/sage/meetings/ 2014/october/1_Report_WORKING_GROUP_vaccine_hesitancy_final.pdf+\&cd= $1 \& \mathrm{hl}=\mathrm{fr} \& \mathrm{ct}=\mathrm{clnk} \& \mathrm{gl}=\mathrm{fr} \& \mathrm{client}=$ firefox-b

[24] Rungtusanatham M. Let's Not Overlook Content. Validity 1998;4.

[25] Harris PA, Taylor R, Minor BL, Elliott V, Fernandez M, O'Neal L, et al. The REDCap consortium: Building an international community of software platform partners. J Biomed Inform 2019;95.

[26] Mead D, Moseley L. The use of the Delphi as a research approach. Nurse Res 2001:8(4):4-23.

[27] Hasson F, Keeney S, McKenna H. Research guidelines for the Delphi survey technique. J Adv Nurs 2000 Oct;32(4):1008-15.

[28] Research Methods in Family Therapy: Second Edition [Internet]. [cited 2019 Sep 13]. Available from: https://www.guilford.com/books/Research-Methodsin-Family-Therapy/Sprenkle-Piercy/9781572309609/contents.

[29] The Delphi method | The Psychologist [Internet]. [cited 2019 Aug 14]. Available from: https://thepsychologist.bps.org.uk/volume-22/edition-7/ delphi-method.
[30] Dalkey N, Helmer O. An Experimental Application of the DELPHI Method to the Use of Experts. Manag Sci 2019;9(3):458-67. http://pubsonline.informs. org/doi/abs/10.1287/mnsc.9.3.458.

[31] Marti M, de Cola M, MacDonald NE, Dumolard L, Duclos P. Assessments of global drivers of vaccine hesitancy in 2014-Looking beyond safety concerns. PLoS ONE 2017;12(3)

[32] Perez S, Shapiro GK, Tatar O, Joyal-Desmarais K, Rosberger Z. Development and Validation of the Human Papillomavirus Attitudes and Beliefs Scale in a National Canadian Sample. Sex Transm Dis 2016 Oct:43(10):626-32.

[33] Perez S, Tatar O, Ostini R, Shapiro GK, Waller J, Zimet G, et al. Extending and validating a human papillomavirus (HPV) knowledge measure in a national sample of Canadian parents of boys. Prev Med 2016;91:43-9.

[34] Larson HJ, de Figueiredo A, Xiahong Z, Schulz WS, Verger P, Johnston IG, et al. The State of Vaccine Confidence 2016: Global Insights Through a 67-Country Survey. EBioMedicine 2016 Oct;12:295-301.

[35] Hyland ME, Lewith GT, Westoby C. Developing a measure of attitudes: the holistic complementary and alternative medicine questionnaire. Complement Ther Med 2003 Mar;11(1):33-8.

[36] The Vaccine Confidence Project [Internet]. [cited 2019 Sep 13]. Available from: https://www.vaccineconfidence.org/.

[37] Salkind N. Encyclopedia of Measurement and Statistics [Internet]. 2455 Teller Road, Thousand Oaks California 91320 United States of America: Sage Publications, Inc.; 2007 [cited 2020 Jun 19]. Available from: http://methods. sagepub.com/reference/encyclopedia-of-measurement-and-statistics.

[38] Neuer Colburn AA, Grothaus T, Hays DG, Milliken T. A Delphi Study and Initial Validation of Counselor Supervision Competencies. Couns Educ Superv 2016;55(1):2-15. cited 2019 Aug 17] http://doi.wiley.com/10.1002/ceas. 12029.

39] McDermott DS. The Prebriefing Concept: A Delphi Study of CHSE Experts. Clin Simul Nurs 2016;12(6):219-27. https://linkinghub.elsevier.com/retrieve/pii/ S1876139916000190.

[40] Lawshe CH. A QUANTITATIVE APPROACH TO CONTENT VALIDITY. Pers Psychol [Internet] 1975;28(4):563-75. http://doi.wiley.com/10.1111/j.17446570.1975.tb01393.x.

[41] McRee A-L, Brewer NT, Reiter PL, Gottlieb SL, Smith JS. The Carolina HPV immunization attitudes and beliefs scale (CHIAS): scale development and associations with intentions to vaccinate. Sex Transm Dis. 2010 Apr;37 (4):234-9.

[42] Lane S, MacDonald NE, Marti M, Dumolard L. Vaccine hesitancy around the globe: Analysis of three years of WHO/UNICEF Joint Reporting Form data2015-2017. Vaccine 2018;36(26):3861-7.

[43] Hoeppner BB, Kelly JF, Urbanoski KA, Slaymaker V. Comparative utility of a single-item versus multiple-item measure of self-efficacy in predicting relapse among young adults. J Subst Abuse Treat 2011 Oct;41(3):305-12.

[44] Marlow LAV, Waller J, Wardle J. Parental attitudes to pre-pubertal HPV vaccination. Vaccine 2007 Mar 1;25(11):1945-52.

[45] Berenson AB, Laz TH, Hirth JM, McGrath CJ, Rahman M. Effect of the decisionmaking process in the family on HPV vaccination rates among adolescents 917 years of age. Hum Vaccines Immunother 2014;10(7):1807-11.

[46] Zimet GD, Mays RM, Sturm LA, Ravert AA, Perkins SM, Juliar BE. Parental attitudes about sexually transmitted infection vaccination for their adolescent children. Arch Pediatr Adolesc Med 2005 Feb;159(2):132-7. 